\title{
La-Faujasite zeolite activated with boron trifluoride: synthesis and application as solid acid catalyst for isobutane-isobutene alkylation
}

\author{
David Bolonio ${ }^{1}$ Yolanda Sánchez-Palencia ${ }^{1}$ María-Jesús García-Martínez ${ }^{1}$ Marcelo F. Ortega ${ }^{1}$. \\ José Eugenio Ortiz ${ }^{1} \cdot$ Jorge Costafreda $^{1} \cdot$ Laureano Canoira $^{1}$ (i)
}

Received: 26 July 2021 / Accepted: 20 September 2021 / Published online: 28 September 2021

(c) The Author(s) 2021

\begin{abstract}
The sodium form of Faujasite Y (Na-FAU) zeolite has been synthesized by the hydrothermal method, and it has been exchanged with ammonium sulphate and later with lanthanum (III) chloride solutions to obtain the La-FAU catalyst. The three zeolites Na-FAU, $\mathrm{NH}_{4}{ }^{+}$-FAU and La-FAU have been characterized by microcrystalline X-ray diffraction, X-ray fluorescence, surface area, pore volume and Brönsted acid sites. The La-FAU catalyst has been successfully activated with boron trifluoride etherate, and it has been tested in the alkylation reaction of isobutane with isobutene up to $112 \mathrm{~h}$ of time on stream, since the raw La-FAU catalyst showed a rapid deactivation.
\end{abstract}

Keywords Faujasite $\cdot$ Lanthanum (III) - Alkylation · Isooctane

\section{Introduction}

The alkylation reaction of isobutane with the $\mathrm{C} 4$ cut from fluid catalytic cracking (FCC) or steam cracking (SC) allows to increase the amount and quality of the gasoline cut in oil refineries. This reaction is carried out in liquid phase at low temperature and pressure, catalyzed by mineral acids like hydrofluoric acid and sulfuric acid. This fact represents a serious drawback, not only due to the corrosive character of these acids, but also due to the high sulfuric acid consumption and the tropism to form aerosols of hydrofluoric acid. Since many years ago, scientists have tried to replace these liquid acids with solid acids, typically zeolites, but the actual fact is that a solid acid catalyst with the performance of the liquid acids remains still to be found [1-4].

The Faujasite-type zeolites all have the same framework structure, and they crystallize with cubic symmetry. The general composition of the unit cell of Faujasite is $\left(\mathrm{Na}_{2}, \mathrm{Ca}, \mathrm{Mg}\right)_{29}\left[\mathrm{Al}_{58} \mathrm{Si}_{134} \mathrm{O}_{384}\right] \cdot 240 \mathrm{H}_{2} \mathrm{O}$. The unit cell

Laureano Canoira

laureano.canoira.lopez@upm.es

1 Environmental Studies Research Group GEA-UPM, ETS Ingenieros de Minas y Energía, Universidad Politécnica de Madrid, Ríos Rosas 21, 28003 Madrid, Spain contains eight cavities, each of diameter $\approx 1.3 \mathrm{~nm}$. The three-dimensional channels, which run parallel to [110], have 12-ring windows with free apertures of about $0.74 \mathrm{~nm}$. The difference between zeolites $\mathrm{X}$ and $\mathrm{Y}$ is in their $\mathrm{Si} / \mathrm{Al}$ ratios which are $1-1.5$ and $1.5-3$, respectively.

Faujasite-type zeolites are one of the most important classes of zeolitic materials and are largely used in industrial processes such as FCC, isomerisation, alkylation and organics and air separations. Y-zeolite is important as catalyst for the industrial reactions in the petroleum refining and petrochemistry such as cracking, hydrocracking, and isomerization. The $\mathrm{Si} / \mathrm{Al}$ ratio is enhanced by dealumination of $\mathrm{NH}_{4}-\mathrm{Y}$ for their practical application at high-temperature reactions. The resulting materials are hydrothermally more stable (the so-called ultrastable Y zeolite, USY). The main component of fluid catalytic cracking (FCC) catalysts is rare earth-containing USY zeolites.

In this work, a catalyst based on zeolite Na-Faujasite has been prepared by hydrothermal synthesis and ionic exchange with a $\mathrm{La}^{3+}$ salt. This catalyst has been tested in the alkylation reaction of isobutane $\left(\mathrm{iC}_{4}\right)$ with isobutene $\left(\mathrm{iC}_{4}{ }^{ }\right)$, which can be considered as a model of the industrial process, since the main alkylation product, 2,2,4-trimethylpentane $\left(2,2,4-\mathrm{TMP}\right.$, isooctane, $\left.i C_{8}\right)$ is the reference compound for the octane rating of gasolines. The sodium form of the zeolite Faujasite has been converted to the acid form by ionic 
exchange with lanthanum (III) chloride, since exchanging with rare earth cations greatly improve the hydrothermal stability of zeolites [5]. The hydrolysis of the $\mathrm{La}^{3+}$ cations produced Brönsted acid sites, after Eqs. 1 and 2, where the negative charges of the zeolite framework are neutralized by hydroxylated lanthanum cations and protons:

$3 \mathrm{Y}^{-} \mathrm{La}\left(\mathrm{H}_{2} \mathrm{O}\right)^{3+} \rightarrow 2 \mathrm{Y}^{-} \mathrm{La}(\mathrm{OH})^{2+}+\mathrm{Y}^{-} \mathrm{H}^{+}$,

$3 \mathrm{Y}^{-} \mathrm{La}\left(\mathrm{H}_{2} \mathrm{O}_{2}\right)^{3+} \rightarrow \mathrm{Y}^{-} \mathrm{La}(\mathrm{OH})_{2}^{+}+2 \mathrm{Y}^{-} 2 \mathrm{H}^{+}$.

X-zeolite [6, 7], Y-zeolite [8-10] and HZSM-5 [11] zeolite have been used previously for this alkylation reaction. Zeolite catalysts have been also tested for the etherification reaction of methanol or ethanol and isobutene, to produce Methyl tert-Butyl Ether (MTBE) and Ethyl tert-Butyl Ether (ETBE), respectively, well used octane boosters for gasoline $[12,13]$. Apart from its antiknock characteristics, alkylate oil is also known for its clean burning characteristics due to the absence of sulphur, olefins, and aromatics.

With the use of catalyst based on Faujasite zeolite for alkylation, the refinery could avoid the dangerous use of corrosive liquid acids, that could also leach some sulphur to the fuel streams. The novelty of this work is the activation of a rapidly deactivated La-Faujasite catalyst with boron trifluoride etherate, that allow maintain the catalyst activity for $112 \mathrm{~h}$ on stream.

\section{Experimental section}

\section{Equipment}

The zeolite Na-Faujasite syntheses were carried out in a $1 \mathrm{~L}$ autoclave Büchiglasuster. The ionic exchange of the zeolite catalysts was carried out in a $1 \mathrm{~L}$ stirred glass tank reactor with a heating jacket, controlled with a type-K thermocouple and a proportional integrative differential (PID) controller from PID Eng model TC-10.

The reactor used for the reaction experiments was a stainless steel (SS) tubular reactor $(47.5 \mathrm{~cm}$ length $\times 4.0 \mathrm{~cm}$ o.d.), heated by three independent heating jackets, which were controlled by an adaptive predictive control software from SCAP [14]. This reactor was connected: upstream to a stainless steel $(\mathrm{SS})$ vaporizer $(10.5 \mathrm{~cm}$ length $\times 5.0 \mathrm{~cm}$ o.d.) filled with glass Raschig rings, and downstream consecutively to: (i) a SS heat exchanger (tube and shell, $15.5 \mathrm{~cm}$ length $\times 5.0 \mathrm{~cm}$ o.d.) cooled by an ethylene glycol-water solution using a circulation pump from Electro AD model H-5P3; (ii) a SS gas-liquid separator $(15.5 \mathrm{~cm}$ length $\times 5.0 \mathrm{~cm}$ o.d.), and (iii) a SS liquid storing tank $(10.5 \mathrm{~cm}$ length $\times 5.0 \mathrm{~cm}$ o.d.).
The feed of gases (isobutane, isobutene, synthetic air and nitrogen) was controlled using mass flow controllers from Brook Instrument BV, model 5850 TR, with a range 0-6 $\mathrm{NL} / \mathrm{h}$ and $1 \%$ accuracy. The back pressure regulator was also from Brook Instrument BV, model 5866, with a range $0-2$ bar $(0-20 \mathrm{hPa})$ and $0.5 \%$ accuracy. The feed of liquids was done with a linear actuator from Sage Instruments, model $341 \mathrm{~B}$, with a speed range from 0.022 to $0.321 \mathrm{~m} / \mathrm{h}$, and a flow range from 0.67 to $180 \mathrm{~mL} / \mathrm{h}$ depending on the syringe size. All connections between these items of equipment were done with $1 / 4$ " SS tube using Hoke fittings and electro-valves from Hirschmann model 12B GDM. Pressure measurements were carried out with a sensor DS-Europe, model LP634, and temperature measurements were done with type-K thermocouples from Sirsa SA. Figure 1 shows a scheme of this pilot plant.

X-ray diffraction analysis (XRD) of microcrystalline solids were carried out in an instrument PANalytical PW1710 with copper $\mathrm{K} \alpha$ radiation $(\lambda=0.154 \mathrm{~nm})$ set at $40 \mathrm{kV}$ and $40 \mathrm{~mA}$, scanning from $4^{\circ}$ to $60^{\circ}$ at $2^{\circ} / \mathrm{min}$.

$\mathrm{X}$-ray fluorescence analysis (XRF) were carried out in a wavelength dispersive instrument PANalytical PW1404 with Sc-Mo tube, using pearls of lithium tetraborate. For the analysis of lanthanum, pressed pellets have been used, since the pearls were elaborated with a tiny amount of lanthanum oxide.

Atomic absorption spectrophotometry analyses were carried out in an instrument Philips PU9100X with a $\mathrm{N}_{2} \mathrm{O} / \mathrm{C}_{2} \mathrm{H}_{2}$ flame and selecting for B analysis the line with $\lambda=249.8 \mathrm{~nm}$.

Gas chromatography analysis (GC-FID) was carried out in a chromatograph Agilent 5840 with FID detector, in the analytical conditions shown in Table 1 .

Thermogravimetric analysis (TGA) was carried out in an instrument TGA2 Mettler heating the sample from ambient temperature to $800{ }^{\circ} \mathrm{C}$ at a rate of $10{ }^{\circ} \mathrm{C} / \mathrm{min}$ under a constant nitrogen flow.

\section{Materials}

Neutral sodium silicate solution, with $27 \% \mathrm{w} / \mathrm{w}$ of $\mathrm{SiO}_{2}$ and $8 \% \mathrm{w} / \mathrm{w}$ of $\mathrm{Na}_{2} \mathrm{O}$ was bought from Panreac. Sodium aluminate, ammonium sulphate and sodium hydroxide were bought from Probus. Lanthanum (III) chloride was bought from Merck. Boron trifluoride etherate and isooctane were bought from Sigma-Aldrich. High purity isobutane (>99.9\%) and isobutene (>99.9\%) were bought from Air Liquide and they were used without further purification.

Table 2 summarizes the composition of the nucleation and crystallization gels, for a total reaction volume of $500 \mathrm{~mL}$ and $20 \% \mathrm{w} / \mathrm{w}$ of nucleation gel, and the amounts of the above commercial reagents necessary to achieve these compositions. 


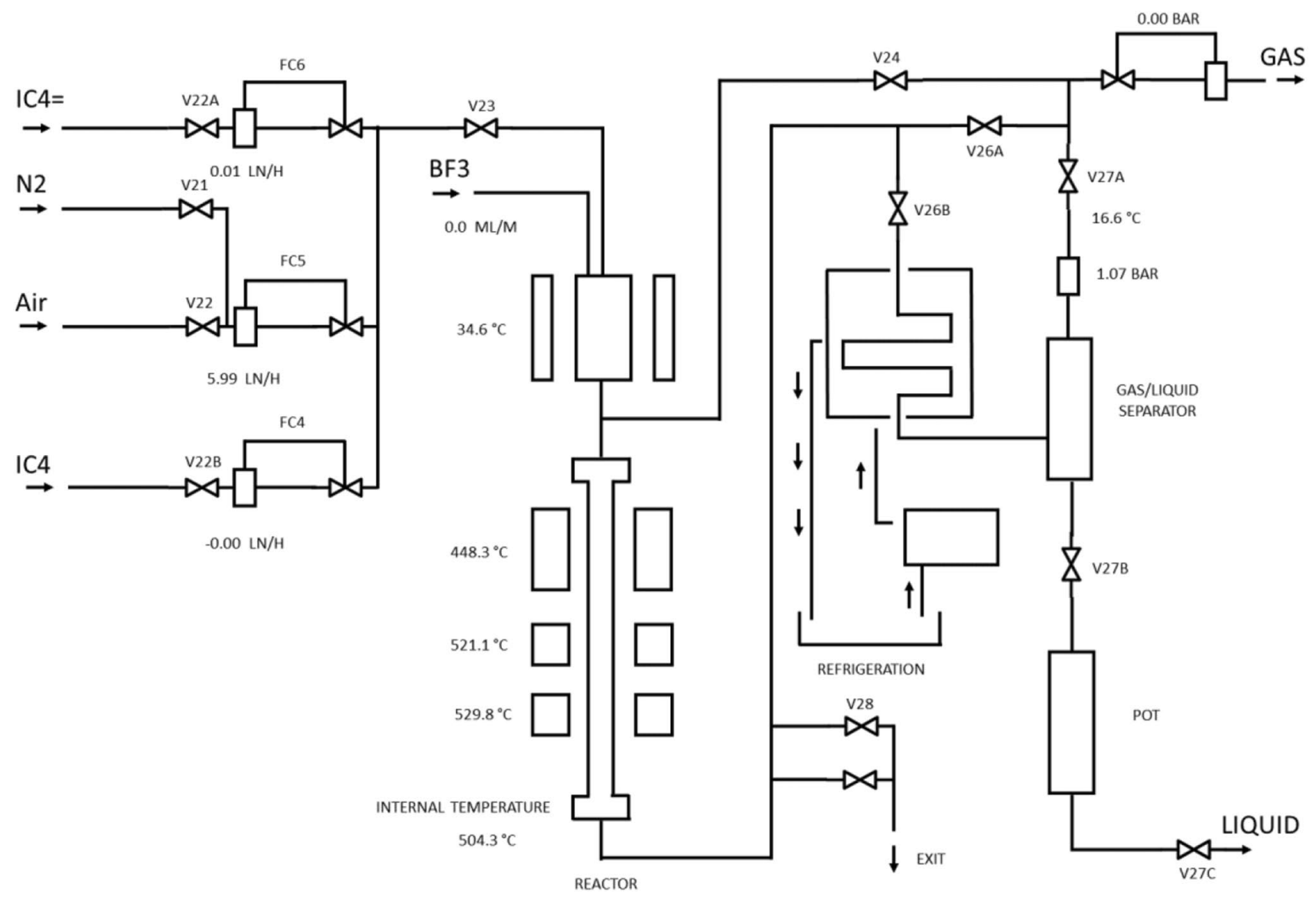

Fig. 1 Scheme of the pilot plant

Table 1 GC-FID parameters

\begin{tabular}{ll}
\hline GC column & $\begin{array}{l}\text { Stainless steel, packed, } 3 \mathrm{~m} \times 0.3175 \mathrm{~cm}, \\
\text { HP } 10 \% \text { UCV phase on Chromosorb AW } \\
80 / 100 \text { mesh }\end{array}$ \\
\hline Initial temperature, ${ }^{\circ} \mathrm{C}$ & 40 \\
Initial time, min & 3 \\
Rate, ${ }^{\circ} \mathrm{C} /$ min & 10 \\
Final temperature, ${ }^{\circ} \mathrm{C}$ & 175 \\
Final time, min & 10 \\
Injector temperature, ${ }^{\circ} \mathrm{C}$ & 200 \\
FID temperature, ${ }^{\circ} \mathrm{C}$ & 200 \\
He Flow, mL/min & 7 \\
Injection device & Hamilton precision syringes, $100 \mu \mathrm{L} / 10 \mu \mathrm{L}$ \\
\hline
\end{tabular}

\section{Catalyst preparation}

\section{Formation of the nucleation gel}

In the autoclave, the sodium hydroxide was dissolved in distilled water at room temperature, and later the sodium
Table 2 Reagents amounts for the synthesis of zeolite Na-Faujasite

\begin{tabular}{lccl}
\hline Parameter & Nucleation gel & Crystallization gel & Difference \\
\hline $\mathrm{SiO}_{2} / \mathrm{Al}_{2} \mathrm{O}_{3}$ & 3.444 & 10.00 & - \\
$\mathrm{Na}_{2} \mathrm{O} / \mathrm{SiO}_{2}$ & 1.463 & 0.505 & - \\
$\mathrm{H}_{2} \mathrm{O} / \mathrm{Na}_{2} \mathrm{O}$ & 35.93 & 35.42 & - \\
$\mathrm{SiO}_{2}$, mol & 0.1056 & 1.5438 & - \\
$\mathrm{Al}_{2} \mathrm{O}_{3}$, mol & 0.0307 & 0.1543 & - \\
$\mathrm{Na}_{2} \mathrm{O}$, mol & 0.1546 & 0.7842 & - \\
$\mathrm{H}_{2} \mathrm{O}$, mol & 5.55 & 27.7 & - \\
Sodium silicate, g & 23.47 & 343.5 & 320.05 \\
Sodium aluminate, g & 5.035 & 25.32 & 20.285 \\
Sodium hydrox- & 7.72 & 15.60 & 7.89 \\
$\quad$ ide, g & & & 191.96 \\
Distilled water, mL & 84.75 & 276.71 & \\
\hline
\end{tabular}

aluminate was added, stirring the mixture until complete dissolution of both reagents. Afterwards, the sodium silicate was slowly added, forming a gel which was stirred at $500 \mathrm{rpm}$ during $1 \mathrm{~h}$. This nucleation gel was left standing at room temperature for $48 \mathrm{~h}$ without any agitation. 


\section{Crystallization procedure}

One hour before the end of the nucleation gel aging, a new gel was prepared in exactly the same way as indicated for the nucleation gel, but with the reagent amounts shown in the Difference column of Table 2. This gel was stirred at $500 \mathrm{rpm}$ for $1 \mathrm{~h}$. After aging, the nucleation gel was activated heating it at $60{ }^{\circ} \mathrm{C}$ in a water bath, and it was mixed with the recently prepared additional gel at $60^{\circ} \mathrm{C}$ under stirring. This full crystallization gel was stirred at $500 \mathrm{rpm}$ in the autoclave until the crystallization temperature of $100{ }^{\circ} \mathrm{C}$ was reached. Afterwards, the reaction mixture was kept at $100{ }^{\circ} \mathrm{C}$ without stirring during $4 \mathrm{~h}$. Later, the reaction mixture was centrifuged at $1000 \mathrm{rpm}$, the mother liquid was discarded and the solid was washed with distilled water several times, eliminating the washing water by filtration, until neutral $\mathrm{pH}$ was reached in the washing water. The white solid obtained was dried at $120^{\circ} \mathrm{C}$ for $12 \mathrm{~h}$. XRD and XRF analyses showed that it consisted of the sodium form of Faujasite (Na-FAU).

\section{Preparation of the active zeolite Faujasite catalyst}

The sodium form of zeolite Faujasite (Na-FAU) was converted to the catalytically active form by ionic exchange in solution as follows:

To prepare the zeolite catalyst, the sodium form of the zeolite Na-FAU was stirred at room temperature with a $5 \% \mathrm{w} / \mathrm{v}$ solution of ammonium sulphate during $24 \mathrm{~h}$. The solid was filtered and washed until absence of sulphate in the washing waters (checking by silver sulphate precipitation with a diluted solution of silver nitrate). This ionic exchange procedure was repeated three times [4]. To obtain the zeolite La-FAU catalyst, the $\mathrm{NH}_{4}$-FAU zeolite was exchanged with a $0.5 \% \mathrm{w} / \mathrm{v}$ solution of lanthanum (III) chloride for $24 \mathrm{~h}$ at room temperature with stirring. The solid was filtered and washed with distilled water until absence of chlorides in the washing waters (checking by silver chloride precipitation with a diluted solution of silver nitrate). The La-FAU zeolite was dried at $120{ }^{\circ} \mathrm{C}$, and calcined in an oven at $550{ }^{\circ} \mathrm{C}$ overnight, rising the oven temperature at $100{ }^{\circ} \mathrm{C}$ steps and keeping the La-FAU zeolite at each step for $1 \mathrm{~h}$. The amount of La-FAU zeolite was $39.66 \mathrm{~g} \mathrm{(6.0 \%} \mathrm{yield} \mathrm{based} \mathrm{on} \mathrm{crystal-}$ lization gel of Table 2, including water).

The catalysts were prepared with the active form of the zeolite, and the fraction between 0.5 and $1.0 \mathrm{~mm}$ was used for the fixed-bed experiments [10].

\section{Characterization}

$\mathrm{XRD}$ and XRF analyses were carried out on all samples to ascertain the chemical and mineralogical composition of these catalysts, and they are summarized in Tables 3 and
Table 3 Chemical composition of zeolite catalysts by XRF

\begin{tabular}{lllll}
\hline$\% w / w$ & $\mathrm{Na}-\mathrm{FAU}$ & $\mathrm{NH}_{4}$-FAU & La-FAU & La-FAU $^{\mathrm{c}}$ \\
\hline $\mathrm{SiO}_{2}$ & 43.67 & 47.31 & 57.30 & 60.1 \\
$\mathrm{Al}_{2} \mathrm{O}_{3}$ & 18.37 & 20.00 & 25.30 & 25.8 \\
$\mathrm{Na}_{2} \mathrm{O}$ & 13.96 & 2.74 & 4.10 & 3.00 \\
$\mathrm{TiO}_{2}$ & 0.046 & 0.060 & - & - \\
$\mathrm{Fe}_{2} \mathrm{O}_{3}$ & 0.076 & 0.076 & - & - \\
$\mathrm{La}_{2} \mathrm{O}_{3}$ & - & - & 1.40 & 1.40 \\
$\mathrm{SiO}_{2} / \mathrm{Al}_{2} \mathrm{O}_{3}$ & 2.37 & 2.37 & 2.26 & 2.35 \\
$\mathrm{Na}_{2} \mathrm{O} / \mathrm{SiO}_{2}$ & 3.13 & 17.26 & 13.84 & 20.03 \\
$\mathrm{~B}^{\mathrm{a}}$ & - & - & - & 2.6 \\
$\mathrm{Si} / \mathrm{Al} \mathrm{molar}$ ratio & 2.02 & 2.01 & 1.93 & 1.98 \\
$\mathrm{Si} / \mathrm{La}$ molar ratio & - & - & 111.17 & 116.6 \\
$\mathrm{LOI}$ & 22.10 & 19.80 & 11.30 & 7.1 \\
$\Sigma \%$ & 98.22 & 90.00 & 99.40 & 100.0 \\
\hline
\end{tabular}

${ }^{a}$ Analyzed by atomic absorption spectrophotometry after alkylation experiments

${ }^{\mathrm{b}}$ Loss on ignition (LOI)

${ }^{\mathrm{c} C o m p o s i t i o n}$ of zeolite La-FAU catalyst after $112 \mathrm{~h}$ of time on stream (TOS) in alkylation experiments

4. The mineralogical composition of the catalysts and their crystallinity have been determined by XRD following the standard method ASTM D3906-03 (2013), as the average ratio of X-ray counts of selected diffraction peaks in the samples and in a supposedly full crystalline Na-FAU zeolite taken as reference.

The BET surface and pore volume of the catalysts were analyzed by nitrogen adsorption-desorption isotherms in a Micromeritics ASAP-2010 instrument and the results are summarized in Table 5. Prior to the measurements, all samples were degassed at $300{ }^{\circ} \mathrm{C}$ under vacuum overnight.

The acid site strength was investigated by temperature programmed ammonia desorption $\left(\mathrm{NH}_{3}-\mathrm{TPD}\right)$ on an ASAP 2920 analyzer. Before the measurement, approximately $0.1 \mathrm{~g}$ dry samples were degassed under $\mathrm{He}$ flow at $500{ }^{\circ} \mathrm{C}$ for $1 \mathrm{~h}$. After cooling to $120{ }^{\circ} \mathrm{C}$, the sample was exposed to $\mathrm{NH}_{3}$ $(10 \% \mathrm{v} / \mathrm{v})-\mathrm{He}$ gas flow for $30 \mathrm{~min}$. Then, the sample was swept by He for $1 \mathrm{~h}$ to remove the physically adsorbed $\mathrm{NH}_{3}$, and the TPD was carried out from 120 to $600{ }^{\circ} \mathrm{C}$ using a heating rate of $10^{\circ} \mathrm{C} \mathrm{min}^{-1}$.

\section{Alkylation reaction}

The catalyst La-FAU was placed in the bottom section of the tubular reactor supported on rockwool and prior to each reaction it was activated in air at $538^{\circ} \mathrm{C}$ during $2 \mathrm{~h}$. Isobutane, isobutene and nitrogen as diluent were fed to the reactor in the mass flows required for each experiment, that lasted for about $8 \mathrm{~h}$, at a weight hourly spatial velocity (WHSV) defined in Eq. 3: 
Table 4 X-ray counts of zeolite catalysts by XRD

\begin{tabular}{lllllll}
\hline $2 \theta\left(^{\circ}\right)$ & $\mathrm{Na}^{\circ} \mathrm{FAU}^{\mathrm{a}}$ & $\mathrm{Na}-\mathrm{FAU}$ & $\mathrm{NH}_{4}$-FAU & La-FAU & La-FAU $^{\mathrm{b}}$ & La-FAU $^{\mathrm{c}}$ \\
\hline $15.3-15.9$ & 327 & 281 & 133 & 53 & 36 & - \\
$18.5-18.9$ & 109 & 100 & 78 & 27 & 18 & - \\
$20.1-20.7$ & 178 & 156 & 103 & 35 & 24 & - \\
$23.7-24.1$ & 328 & 344 & 192 & 67 & 41 & - \\
$26.6-27.6$ & 215 & 220 & 129 & 32 & 20 & 86 \\
$30.3-31.3$ & 108 & 83 & 44 & 8 & - & - \\
$31.0-32.0$ & 290 & 228 & 94 & 26 & 17 & - \\
$33.6-34.8$ & 61 & 72 & 41 & 10 & - & - \\
Ecounts & 1616 & 1484 & 814 & 258 & 156 & 86 \\
Mean & 202 & 185.5 & 101.8 & 32.3 & 26 & 10.8 \\
Crystall.,\% & 100.0 & 91.8 & 50.3 & 16.0 & 12.9 & 5.3 \\
\hline
\end{tabular}

${ }^{\mathrm{a}} \mathrm{Na}-\mathrm{FAU}$ zeolite taken as reference

${ }^{\mathrm{b}}$ Crystallinity of zeolite La-FAU catalyst after $56 \mathrm{~h}$ TOS

${ }^{\mathrm{c}}$ Crystallinity of zeolite La-FAU catalyst after $112 \mathrm{~h}$ TOS
Table 5 BET Surface, micropore volume and total acidity of the zeolite catalysts

\begin{tabular}{llll}
\hline Sample & Na-FAU & $\mathrm{NH}_{4}$-FAU & La-FAU \\
\hline $\mathrm{S}_{\mathrm{BET}}, \mathrm{m}^{2} / \mathrm{g}$ & 498 & 497 & 489 \\
$\mathrm{~V}_{\text {micro }}, \mathrm{cm}^{3} / \mathrm{g}$ & 0.207 & 0.206 & 0.202 \\
Acidity, $\mathrm{mmol} \mathrm{NH}_{3} / \mathrm{g}$ & 1.003 & 1.002 & 0.988 \\
\hline
\end{tabular}

$\mathrm{WHSV}=\frac{m_{i C 4}^{=}+m_{i C 4}}{m_{\text {catalyst }}}$

where $m_{i C 4}=$ was the mass flow of isobutene in $\mathrm{g} / \mathrm{h}, m_{i C 4}$ was the mass flow of isobutane in $\mathrm{g} / \mathrm{h}$ and $m_{\text {catalyst }}$ was the catalyst mass in $\mathrm{g}$.

All experiment were carried out in vapor phase, and the reactor effluents were sampled with a $100 \mu \mathrm{L}$ gas syringe through a septum placed at the reactor outlet and were immediately injected in the GC. A heating wire was installed at the reactor outlet to avoid condensation of any liquid products before sampling. After each experiment, the catalyst was purged with a nitrogen flow of $6 \mathrm{NL} / \mathrm{h}$ for $2 \mathrm{~h}$ at $500{ }^{\circ} \mathrm{C}$ to desorb all products occluded in the zeolite channels.

The isobutene conversion (isobutene was always the limiting reagent) was calculated from Eq. 4 :

Isobutene conversion $=\frac{A_{\text {isobut }}-A_{\text {exp }}}{A_{\text {isobut }}} \times 100$,

where $A_{\text {isobut }}$ represent the peak area of isobutene detected in the chromatogram when the reaction system is run without any catalyst, and $A_{\text {exp }}$ represent this same peak area in each experiment with catalyst.

The 2,2,4-TMP selectivity was calculated from Eq. 5:
Isooctane selectivity, $S i_{C 8}=\frac{A_{i C 8}}{A_{i C 8}+A_{\text {others }}} \times 100$,

where $A_{i C 8}$ is the peak area of isooctane and $A_{\text {others }}$ is the peak area of other alkylation and isobutene oligomerization products.

\section{Results and discussion}

\section{Catalyst characterization}

The chemical composition of zeolites prepared in this work was analyzed by XRF and it is summarized in Table 3. Faujasite-type zeolites with $\mathrm{Si} / \mathrm{Al}$ ratio near one are usually denoted by $\mathrm{X}$-zeolite, whereas, those with $\mathrm{Si} / \mathrm{Al}$ ratio higher than two are usually denoted by Y-zeolite. The Si/ Al molar ratio for all zeolites in this study is around 2.0, which means that it could be possible that some of the aluminium atoms are extra-framework (EFAL), and they could be exchanged to increase the acid strength of the catalyst. The ion exchange procedures greatly decrease the crystallinity of the zeolites, thus the Na-FAU prepared in this work has almost the same crystallinity (92\%) as the reference NaFAU, but the La-FAU retains only $16 \%$ crystallinity with respect to reference. Figures 2, 3, 4, 5, 6 show the diffractograms of the FAU zeolites, where the decrease of crystallinity with time on stream is evident. However, the BET surface, the total micropore volume and the acidity results remain practically unaffected by the ionic exchange, which differs from previously reported results [8]. The BET surface of this work catalyst (Table 5) is slightly higher than the value of $470 \mathrm{~m}^{2} / \mathrm{g}$ reported for other alkylation catalysts, and the pore volume somewhat lower than the values between 0.255 and $0.295 \mathrm{~cm}^{3} / \mathrm{g}$ also reported [6]. 
Fig. 2 DRX of Na-FAU

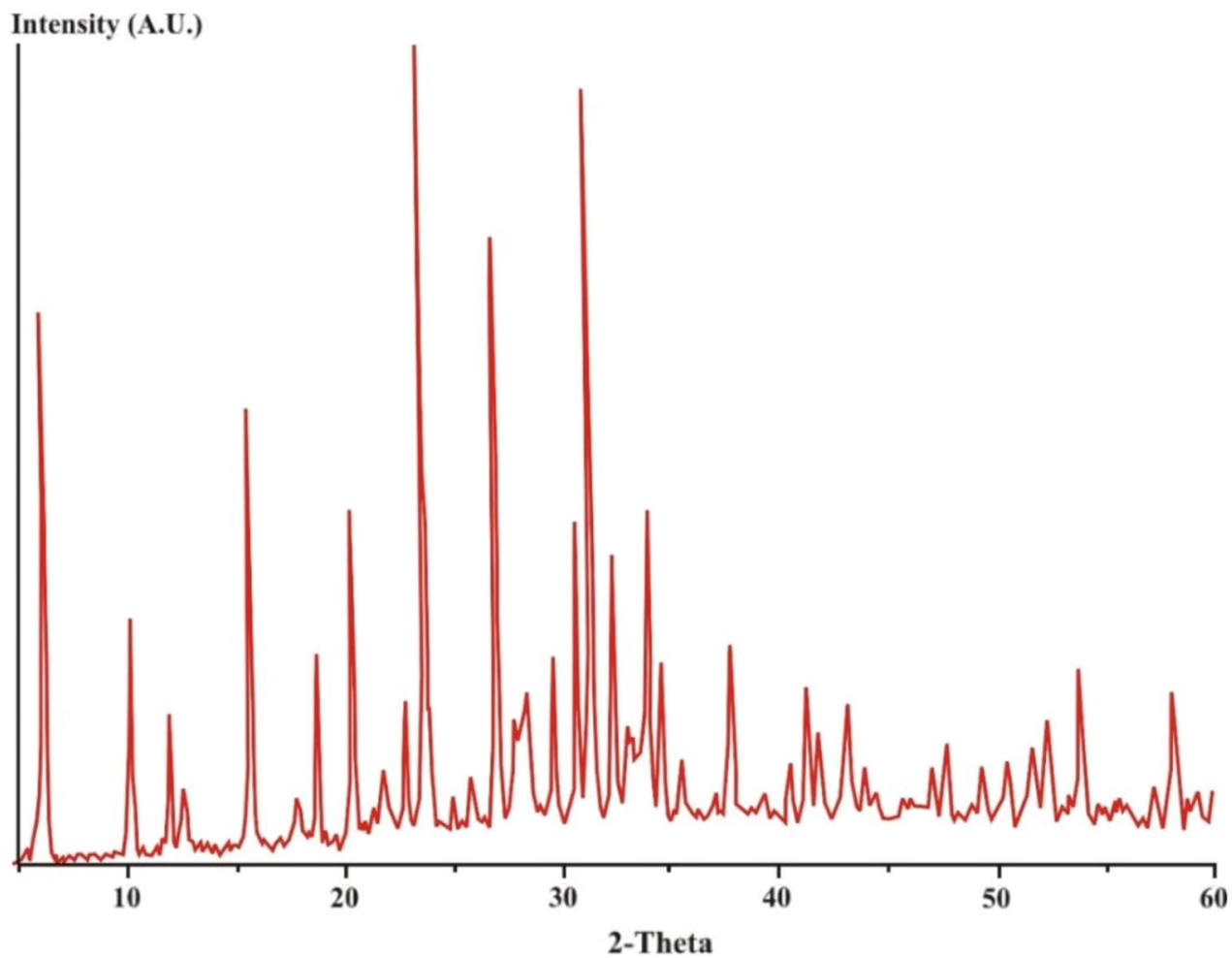

Fig. 3 DRX of $\mathrm{NH}_{4}{ }^{+}$-FAU

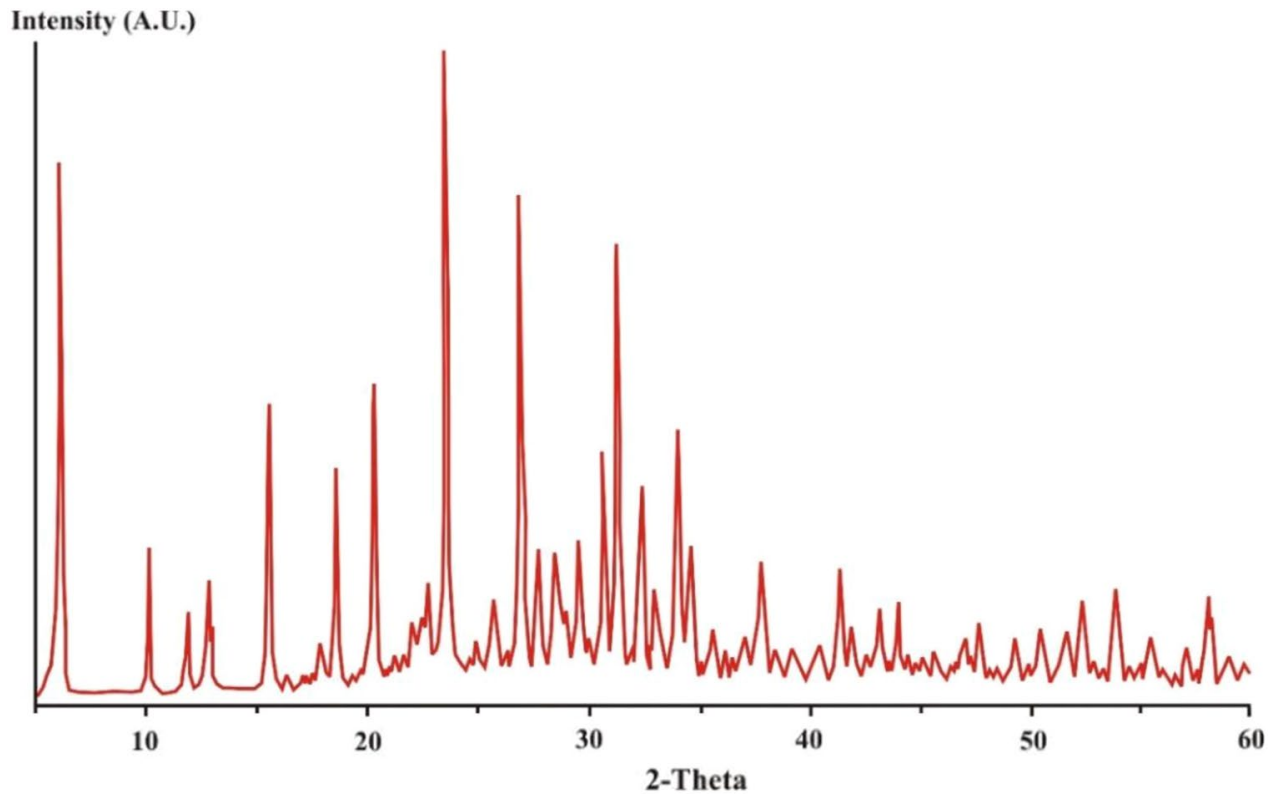

\section{La-FAU catalyst activation}

The La-FAU catalysts showed a quick deactivation in the first alkylation experiments after a few minutes on stream [3]. Thus, it was activated by treatment with boron trifluoride etherate, injecting this solution $(0.06 \mathrm{~mL} / \mathrm{min})$ with the isobutane/isobutene feed (molar ratio $i C_{4} / i C_{4}=$ 5.0, temperature $90{ }^{\circ} \mathrm{C}, W H S V 0.2 \mathrm{~h}^{-1}, i C_{4}$ flow 3.70
$\mathrm{NL} / \mathrm{h}, i C_{4}=$ flow $0.74 \mathrm{NL} / \mathrm{h}$ ). This activated La-FAU catalyst showed an activity equal to the original catalysts, that remained after $112 \mathrm{~h}$ TOS. In fact, the effect of boron could be due to the substitution of the extra-framework (EFAL) aluminium atoms by boron atoms, since boron appears in the chemical analysis of the catalyst after all the alkylation reactions in $2.6 \% \mathrm{w} / \mathrm{w}$, see Table 3 . 


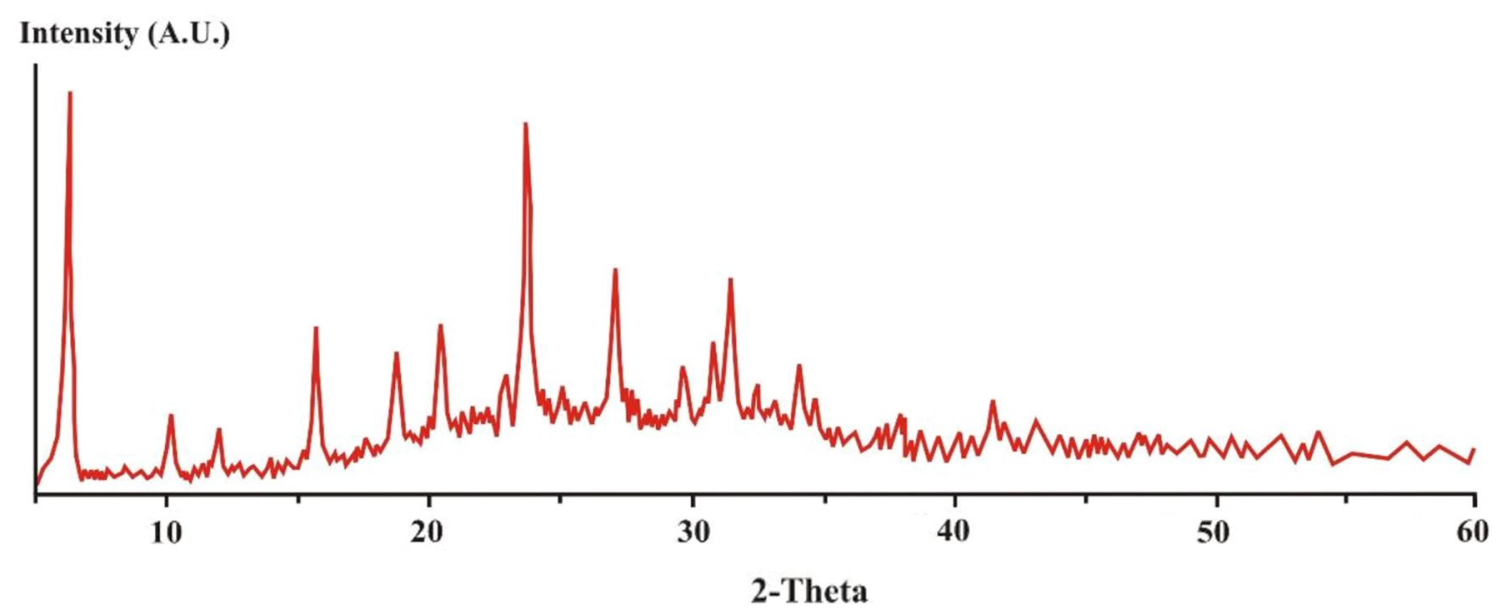

Fig. 4 DRX of calcined La-FAU

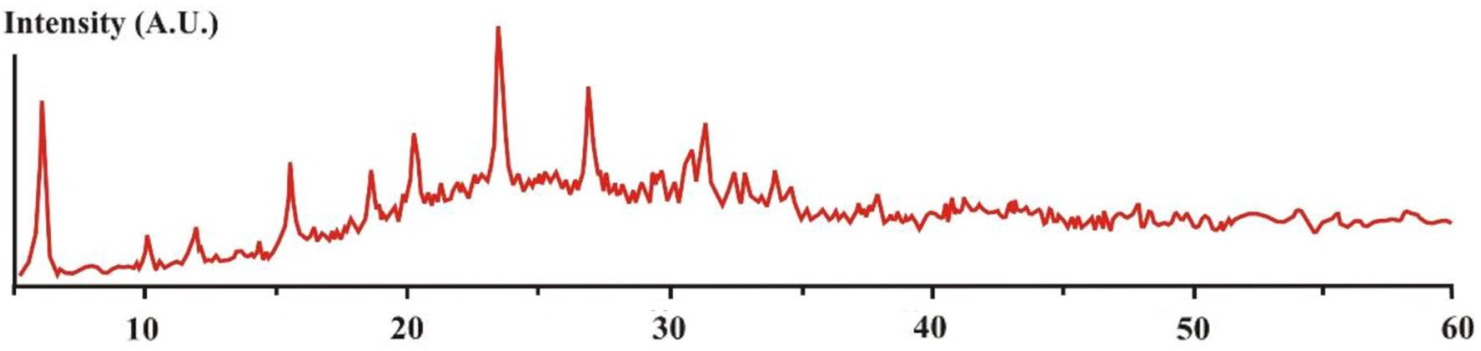

2-Theta

Fig. 5 DRX of La-FAU after $56 \mathrm{~h}$ TOS

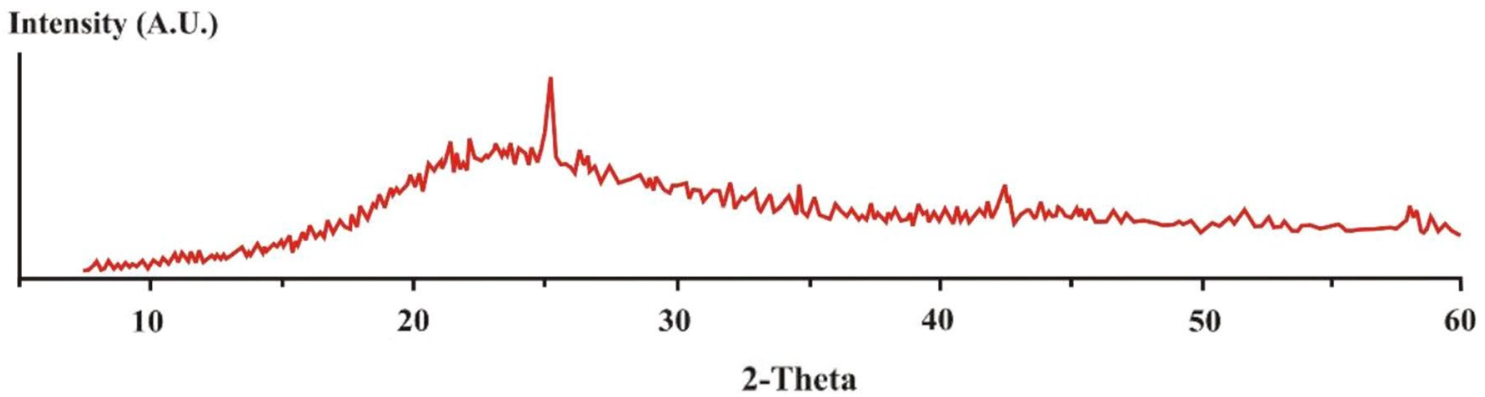

Fig. 6 DRX of La-FAU after 112 h TOS

\section{Alkylation reaction}

This reaction of isobutane with isobutene was carried out as a model reaction for the alkylation of isobutane with the $\mathrm{C}_{4}$ cut from FCC, where isobutene is the most reactive component of this $\mathrm{C}_{4}$ fraction. The product analyzed was 2,2,4-trimethylpentane (2,2,4-TMP, isooctane, $\left.i C_{8}\right)$, although obviously other branched $\mathrm{C}_{8}$ and higher molecular weight compounds $\mathrm{C}_{9}{ }^{+}$are produced in this alkylation. The
$\mathrm{C}_{8}$ fraction is composed of other trimethylpentanes apart from 2,2,4-TMP (2,3,3-TMP and 2,3,4-TMP), dimethylhexanes (DMH) (2,4-DMH, 2,5-DMH and 3,4-DMH), $\mathrm{C}_{8}$ olefins, and other $\mathrm{C}_{8}$ alkanes. Isooctane, $i C_{8}, 2,2,4-\mathrm{TMP}$, is the $\mathrm{C}_{8}$ hydrocarbon with the highest research octane number (RON) and motor octane number (MON) of 100 points. These other $\mathrm{C}_{8}$ alkylation and higher molecular weight products $\mathrm{C}_{9}{ }^{+}$have been quantified in the chromatograms, and their areas have been taken into account to calculate the 
isooctane selectivity after Eq. 5. The effect of reagents molar ratio, temperature and $W H S V$ on the isobutene conversion and isooctane selectivity has been studied.

\section{Effect of the molar ratio isobutane/isobutene $\mathrm{iC}_{4} / \mathrm{iC}_{4}=$}

The effect of the molar ratio $\mathrm{iC}_{4} / \mathrm{iC}_{4}=$ was investigated at $90{ }^{\circ} \mathrm{C}$ and WHSV $0.05 \mathrm{~h}^{-1}$, and it is summarized Fig. 7.

The isooctane selectivity remained practically constant, but the isobutene conversion reached a maximum of $65 \%$ between molar ratios 10 and 15 , in good agreement with the molar ratio of 13 for this reaction on La-FAU catalyst, recently reported by Yang et al. [8]. This high molar ratio of isobutane to isobutene is necessary to minimize the isobutene oligomerization reaction, although it means that a great amount of isobutane need to be recycled to make the process economically acceptable.

\section{Effect of the temperature}

The effect of temperature was investigated at molar ratio $i C_{4} /$ $i C_{4}=$ of 15 and $W H S V 0.05 \mathrm{~h}^{-1}$, in the range $70-150{ }^{\circ} \mathrm{C}$, and the results are summarized in Fig. 8.

The highest isooctane selectivity was achieved at $130{ }^{\circ} \mathrm{C}$ but at lower isobutene conversion, 50\%. As it was expected, when increasing the conversion to $65 \%$ at $90{ }^{\circ} \mathrm{C}$, the isooctane selectivity decreased. The optimal temperature found in our experiments maximizing the isooctane selectivity was $130{ }^{\circ} \mathrm{C}$, in disagreement with previously reported results of $80^{\circ} \mathrm{C}$ [6], which gave more importance to the butenes conversion.

\section{Effect of the WHSV}

The effect of the $W H S V$ was investigated at $130{ }^{\circ} \mathrm{C}$ and molar ratio $\mathrm{iC}_{4} / \mathrm{iC}_{4}{ }^{=}$of 15 , and the results are summarized in Fig. 9.

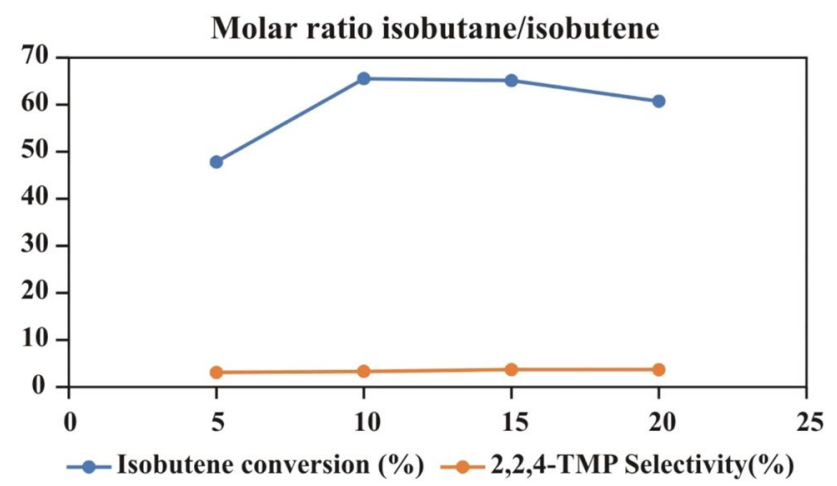

Fig. 7 Effect of the molar ratio isobutane/isobutene $\mathrm{iC}_{4} / \mathrm{iC}_{4}=$
The isooctane selectivity reached the highest value of $15.1 \%$ at $W H S V$ of $0.10 \mathrm{~h}^{-1}$, but with the lowest isobutene conversion of $48.1 \%$.

Thus, it could be estimated that the optimal reaction conditions for this La-FAU catalyst are $130^{\circ} \mathrm{C}$, molar ratio $i C_{4} /$ $i C_{4}=15$ and $W H S V$ of $0.10 \mathrm{~h}^{-1}$.

Figure 10 shows the thermogram of the La-FAU catalyst after one of the alkylation experiments. This thermogram shows one sharp peak at $156{ }^{\circ} \mathrm{C}$, which corresponds to the desorption of the $\mathrm{C}_{8}$ products, isooctane among them, and another much broader peak between 456 and $475{ }^{\circ} \mathrm{C}$, that would represent the desorption of higher molecular weight products, $\mathrm{C}_{9}{ }^{+}$. The adsorption behavior of these catalysts has been reported recently in the literature [15].

The crystallinity of the La-FAU catalyst after $56 \mathrm{~h}$ TOS was slightly lower (13\%) than the that of the new catalyst (16\%), both referred to the Na-FAU taken as crystalline reference. However, after $112 \mathrm{~h}$ TOS, the crystallinity has decreased to 5.3\%, although the La-FAU mass loss of catalyst was negligeable.

The mechanism of this alkylation reaction could be schematized in Fig. 11 [5]:

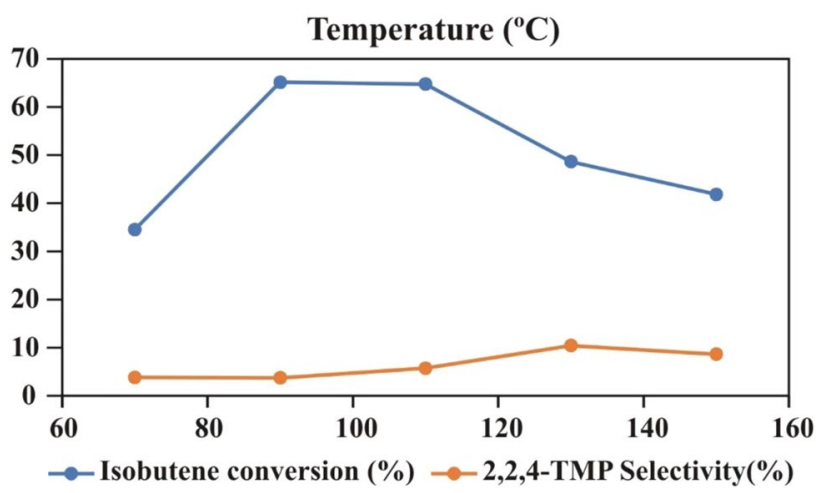

Fig. 8 Effect of the temperature

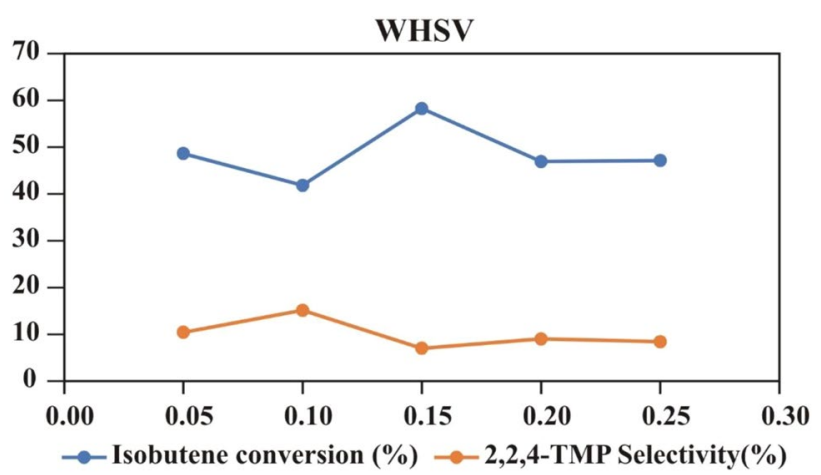

Fig. 9 Effect of the WHSV 


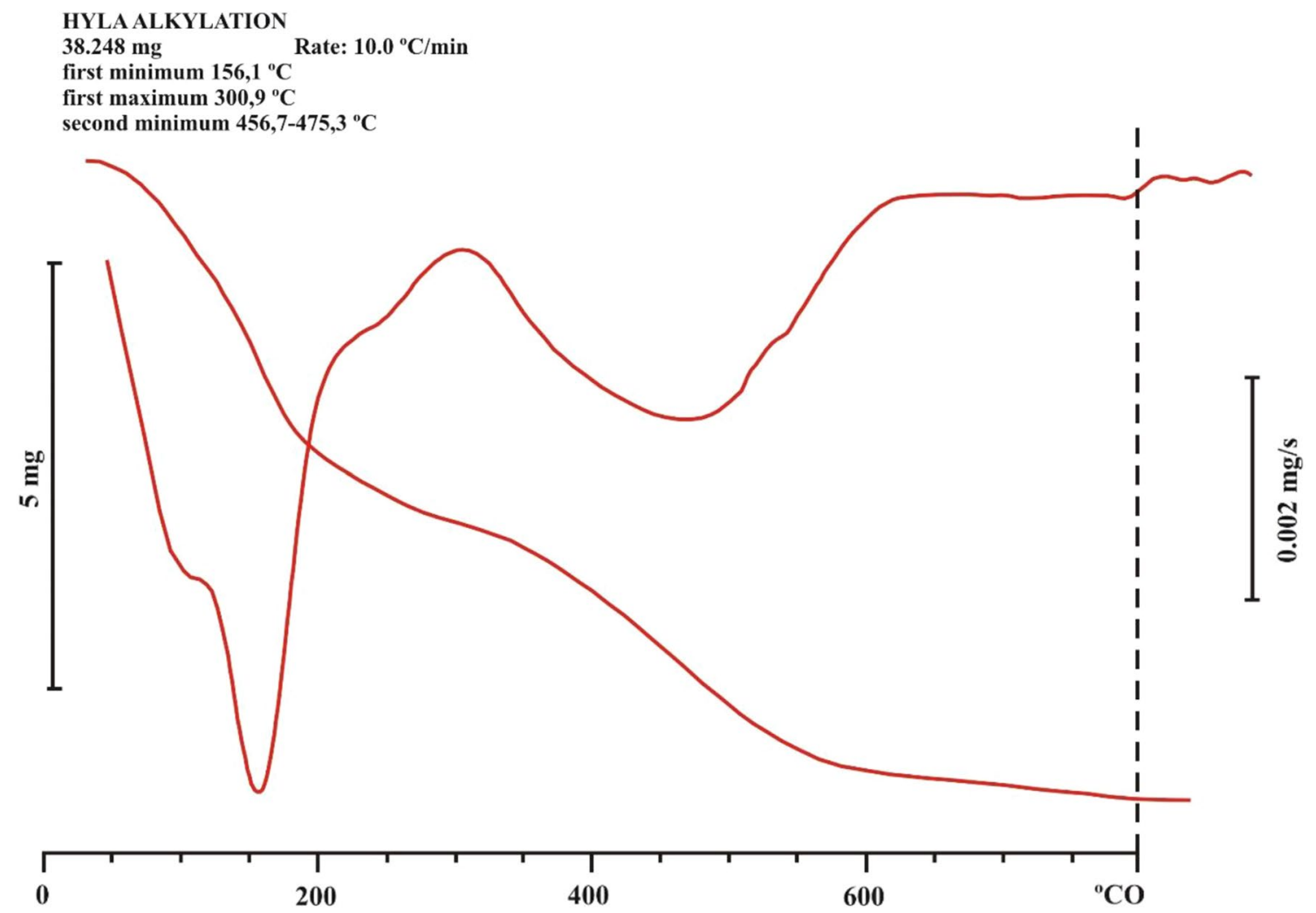

Fig. 10 Thermogram of the La-FAU catalyst after one of the alkylation experiments

Fig. 11 Mechanism of alkylation of isobutane $i C_{4}$ with isobutene $i C_{4}=$ on La-FAU catalyst $\left(\mathrm{F}^{-}\right.$represents zeolite framework)<smiles>C=C(C)CCCCCCC(C)(C)[C+](C)CC(C)(C)C</smiles>

An isobutene $i C_{4}=$ molecule is adsorbed on the Brönsted acid sites and one $\mathrm{H}^{+}$adds to the double bond, giving an adsorbed terc-butyl carbocation. A second isobutene $i C_{4}=$ molecule adsorbs and react with the adsorbed terc-butyl carbocation, giving an adsorbed iso-octyl carbocation. The hydride transfer $\mathrm{H}^{-}$from an adsorbed isobutane molecule 
$i C_{4}$ (present in great excess in the vapor phase) produces the isooctane final molecule that desorbs from the catalyst surface, leaving an adsorbed terc-butyl carbocation coming from the isobutane $i_{4}$ that repeats the mechanistic cycle.

These preliminary alkylation results on La-FAU catalyst show the feasibility of trying this catalyst in a pilot scale plant, avoiding the use of dangerous liquid mineral acids and their environmental problems associated.

\section{Conclusions}

La-FAU Catalyst has been synthesized by hydrothermal method and ion exchange with $\mathrm{La}^{3+}$ solutions, and it has been successfully checked in the alkylation reaction of isobutane with isobutene. The rapidly deactivated original La-FAU catalyst has been reactivated by co-injection of a boron trifluoride etherate during an alkylation experiment, and this catalyst reactivation lasted for at least $112 \mathrm{~h}$ of time on stream.

Acknowledgements The authors wish to thank the European Union for the financial support through program EIT Raw Materials from Horizon 2020 (Project 18259, BioLeach: Innovative Biotreatment of Raw Materials) and UPM student Javier Hernando for technical work.

Open Access This article is licensed under a Creative Commons Attribution 4.0 International License, which permits use, sharing, adaptation, distribution and reproduction in any medium or format, as long as you give appropriate credit to the original author(s) and the source, provide a link to the Creative Commons licence, and indicate if changes were made. The images or other third party material in this article are included in the article's Creative Commons licence, unless indicated otherwise in a credit line to the material. If material is not included in the article's Creative Commons licence and your intended use is not permitted by statutory regulation or exceeds the permitted use, you will need to obtain permission directly from the copyright holder. To view a copy of this licence, visit http://creativecommons.org/licenses/by/4.0/.

\section{References}

1. Corma A, Martínez A (1993) Chemistry, catalysts, and processes for isoparaffin-olefin alkylation: actual situation and future trends. Catal Rev 35(4):483-570. https://doi.org/10.1080/0161494930 8013916

2. Akhmadova KK, Magomadova MK, Syrkin AM, Egutkin NL (2019) History, current state, and prospects for development of isobutane alkylation with olefins. Theor Found Chem Eng 53(4):643-655. https://doi.org/10.1134/S0040579519040092

3. Gerzeliev IM, Temnikova VA, Saitov ZA, Maximov AL (2020) Features of the isobutane alkylation with butylenes on zeolite catalysts. Russ J Appl Chem 93(10):1586-1595. https://doi.org/ $10.1134 / \mathrm{S} 107042722010146$

4. Gerzeliev IM, Temnikova VA, Saitov ZA, Asylbaev DF, Baskhanova MN (2020) Synthesis of a catalyst for isobutane/butylenes alkylation promising for industrial application. Pet Chem 60(10):1170-1175. https://doi.org/10.1134/S0965544120100035

5. Zhang H, Xu J, Tang H, Yang Z, Liu R, Zhang S (2019) Isobutane/2-butene alkylation reaction catalyzed by $\mathrm{Cu}$-modified and rare earth X-type zeolite. Ind Eng Chem Res 58(22):9690 9700. https://doi.org/10.1021/acs.iecr.9b01638

6. Gerzeliev IM, Temnikova VA, Baskhanova MN, Khusaimova DO, Maksimov AL (2019) Effect of the textural characteristics of zeolite catalysts on the main indicators of isobutane alkylation with butylenes. Pet Chem 59(S1):S95-S100. https://doi.org/10.1134/ S096554411913005X

7. Gerzeliev IM, Temnikova VA, Baskhanova MN, Maksimov AL (2020) Alkylation of isobutane with butylenes on catalysts with various $\mathrm{NaX}$ zeolites in the CaLaHX form. Russ J Appl Chem 93(10):1578-1585. https://doi.org/10.1134/S107042722010134

8. Yang Z, Zhang R, Dai F, Tang H, Liu R, Zhang S (2020) Effect of framework $\mathrm{Si} / \mathrm{Al}$ ratios on the catalytic performance of isobutane alkylation over LaFAU zeolites. Energy Fuels 34(8):9426-9435. https://doi.org/10.1021/acs.energyfuels.0c01388

9. Zhou S, Zhang C, Li Y, Shao B, Luo Y, Shu X (2020) A facile way to improve zeolite Y-based catalysts' properties and performance in the isobutane-butene alkylation reaction. RSC Adv 10(49):29068-29076. https://doi.org/10.1039/D0RA03762A

10. Zhou S, Zhang C, Li Y, Luo Y, Shu X (2020) Effect of particle size of A12 O3 binders on acidity and isobutane-butene alkylation performance of zeolite Y-based catalysts. Ind Eng Chem Res 59(13):5576-5582. https://doi.org/10.1021/acs.iecr.9b06280

11. Tonutti LG, Decolatti HP, Querini CA, Dalla Costa BO (2020) Hierarchical H-ZSM-5 zeolite and sulfonic SBA-15: The properties of acidic $\mathrm{H}$ and behavior in acetylation and alkylation reactions. Microporous Mesoporous Mater 305:110284. https://doi. org/10.1016/j.micromeso.2020.110284

12. Agulló F, Alcántara R, Canoira L, Fernández-Sánchez J-M, Navarro A, Neila JR (1998) Continuous flow preparation of methyltert-butyl ether (MTBE) over ZSM-5 catalyst in fixed-bed and fluidized-bed reactors. React Kinet Catal Lett 64(1):161-167. https://doi.org/10.1007/BF02475384

13. Alcántara IMR, Alcántara E, Canoira L, Franco MJ, Navarro A (2000) Gas-phase synthesis of ethyl tert-butyl ether (ETBE) on ZSM-5 catalyst in continuous fixed-bed and fluidized-bed reactors. React Kinet Catal Lett 69:239-246. https://doi.org/10. 1023/A:1005631313062

14. Alcantara R, Canoira L, Conde R, Fernandez-Sanchez JM, Navarro A (1994) Automation of a fixed-bed continuous-flow reactor. J Automat Chem 16(5):187-193

15. Patrylak LK, Yakovenko AV (2021) Alkylation of isobutane with butenes under microcatalytic conditions in pulse mode. Vopr Khimii i Khimicheskoi Tekhnologii 1:55-61. https://doi.org/10. 32434/0321-4095-2021-134-1-55-61

Publisher's Note Springer Nature remains neutral with regard to jurisdictional claims in published maps and institutional affiliations. 